\title{
THERE IS NOTHING NEW UNDER THE SUN: A COMPARATIVE STUDY OF THE POLITICS AT THE TIME OF JESUS TO THE GHANAIAN POLITICS
}

\author{
Dr. Kwaku Boamah ${ }^{1}$ and Isaac Boaheng ${ }^{2}$ \\ ${ }^{1}$ Department of Religions, University of Ghana \\ ${ }^{2}$ University of the Free State, South Africa
}

Cite this article:

Kwaku B., Isaac B. There is Nothing New Under the Sun: A Comparative Study of the Politics at the Time of Jesus to the Ghanaian Politics. African Journal of Social Sciences and Humanities Research 4(3), 116-131. DOI: 10.52589/AJSSHRP9YOZFBQ.

\section{Manuscript History}

Received: 5 June 2021

Accepted: 5 July 2021

Published: 12 July 2021

Copyright $\odot 2020$ The Author(s). This is an Open Access article distributed under the terms of Creative Commons AttributionNonCommercial-NoDerivatives 4.0 International (CC BY-NC-ND 4.0), which permits anyone to share, use, reproduce and redistribute in any medium, provided the original author and source are credited.
ABSTRACT: Generally, it is often said that change is the only constant thing in the world. In other words, as time changes, people's ways of doing things equally change. This paper compares the political culture of first-century Palestine (in which Jesus lived and ministered) to the political culture of contemporary Ghana. The study, therefore, compares and contrasts the reign of Herod in the first century Jerusalem with Political actors in Ghana's Fourth Republic. It is a literaturebased research that draws from both primary and secondary sources. The study found that there is not much difference between the politics of today and that of Jesus' days. It consequently, makes Solomon"s statement - there is nothing new under the sun - still relevant today.

KEYWORDS: Herod, Jesus, Jewish Antiquity, Politics, Ghana 


\section{INTRODUCTION}

Solomon at the end of his life affirmed "The thing that hath been, it is that which shall be; and that which is done is that which shall be done: and there is no new thing under the sun" (Eccl 1:9 KJV). Society seems to move in concentric circles given the way things happen. The motivation for this paper is born out of an answer to a question posed by the Most Rev. Peter Kwasi Sarpong, at the maiden lecture of the Department for Religious Studies and Church Administration of the Catholic Institute of Business and Technology. Speaking on the topic "The Church and Politics: The Ghanaian Experience", The Archbishop Emeritus posed the rhetorical question "Did Christ do politics?" (Sarpong 2016:5). His reflections on the topic enforced the point that the Jews did not separate religion from politics. He stated, Christ "brought about a political revolution far more radical than anything Jews at that time might have had in mind. Every sphere of life, be it, political, economic, social and religious was radically questioned by Jesus and turned upside down" (Sarpong 2016:6).

It is in the light of this question that has motivated the inquiry: What was the practice of politics at the time of Jesus? The purpose of this academic inquiry is to know how political leaders at the time gained political authority, how they ruled the people and how their political administration ended. It is in the light of this curiosity that this paper focuses on a politician around the time of Jesus (Herod the Great) in comparison to the politics of Ghana in the 4th republic. Herod is chosen due to his popularity among Roman, Jewish and Christian scholars as a ruler. The fourth republic is chosen to set the boundaries of this paper and also because it is about the most politically stable period in the history of Ghana.

The paper combines the historical and comparative method to bring out developments from 63 $\mathrm{BC}$ to around $4 \mathrm{AD}$ when factors that led to Pompey's takeover of Jerusalem through the establishment of the Hasmonean monarchy, which established Herod as King at Herod's death. This period is then compared to the Ghanaian fourth republican period from 1992 to 2021. The twenty-nine years of the Ghanaian fourth republican era have seen eight successful elections. The political atmosphere has been dominated by two main political parties. The political developments of the various political parties will be discussed in comparison to that of Herod the Great to find out if the politics of Herod is any different from the situation today in Ghana. It must be emphasized that this paper does not seek to pass any value judgment on the persons and the instances cited. The discussions use the sources without prejudices but for purely academic purposes.

The discussions on Herod are steered by the records of Josephus in the Jewish Antiquity and aspects of the Jewish War. Josephus is described as a diplomat, army general, and historian (Maier 1999:7). Other secondary works and articles by scholars related to the rule of Herod are consulted. Regarding the Ghanaian fourth republican era, newspapers and other articles are also cited. These records are used to identify the similarities and differences between the politics at the time of Jesus and the politics of today, to indicate if there had been changes since the time. 


\section{THE FAMILY AND PERSONALITY OF HEROD THE GREAT}

Herod"'s family background helps to draw a comprehensive picture of who he was and the things he did as a political leader of the Jewish people. His mother was Cypros who was from a distinguished Nabatean family who might have been a convert to Judaism. Herod's father was known as Antipater who was from the Jewish aristocratic class from Idumea known in the Old Testament as Edom and served as an adviser in the court of the Hasmonean King Hyrcanus (Carter 2013:69-70). Herod was a third-generation Edomite Jew born around 72 BC (Dewberry 2013:6). His Edomite or Idumean background made the Jews especially those in Jerusalem dislike him because they saw him as a half-Jew and a Roman collaborator (Powell 2009:27). To endear himself to the Jews, Herod married a Hasmonean daughter Mariamme (Carter 2013:71), a granddaughter of Hyrcanus II. His marriage to Mariamme, though politically motivated, can also be argued that Herod, to some extent, had some affection for her. Herod had four siblings, three brothers (Phasael, Joseph and Pheroras) and a sister (Salome) (Holzapfel 1996-1997:44). Two of his siblings (Joseph and Salome) had Jewish names, which indicate his family"s affinity to Judaism. Herod is believed to have married ten women in his lifetime and had fifteen children: ten sons and five daughters (Holzapfel 1996-1997:55). Josephus describes Herod as sporty, tall, muscular and fast as a young man who as an upperclass son played soldier, hunted and rode horses (Holzapfel 1996-1997:54).

Herod and his brother Phasael were both made tetrarch by Marc Anthony when their father was poisoned but his brother was killed in the Parthian ${ }^{1}$ invasion by Mattathias Antigonus (Ferguson 2003:412). Antigonus was the son of Aristobulus II the last of the Hasmonean brothers who gained power in Judea around $40 \mathrm{BC}$ due to the Parthian invasion (Holzapfel 1996-1997:48). When he became King, he bit off the ear of his uncle Hyrcanus II to disqualify him as a priest, since a priest in Jerusalem must have no physical defect (cf. Lev. 21:18-23; Ferguson 2003:412). Herod was, therefore, fleeing to Rome when he was announced King of the Jews in 40 BC (Carter 2013:70). To gain the kingdom, Herod appealed to Anthony to put Antigonus away to make room for his rulership (see Carter 2013:70). Antigonus was therefore bound to a cross and humiliated by flogging and later killed (Josephus 1998:357). This punishment and shameful death, according to Dio Cassius as cited by Ferguson (2003:413), suggest that no priest and king had ever been treated this way. This incident, therefore, gave room for Herod to begin his rule of the Jews. Herod's rule was therefore begun by the humiliating and the killing of the last Hasmonean king who stood in his way.

\section{THE RULE OF HEROD}

The Jewish people were identified by their ethnic, political and religious convictions. Therefore, owing to Herod's background as a half-Jew, he called himself "King of the Jews." Toher (2011:209) remarks that "Energetic leadership, risk-taking and canny ability to ally himself with the dominant Romans in the region ... secured Herod the kingship of Judaea...for more than thirty-five years." A well-known and oft-cited maxim goes like this, "Herod stole along to the throne like a fox, he ruled like a tiger, and he died like a dog" (Beitzel 2014:310). This assessment accurately reflects Herod's cunning ascension to the throne cunningly, his ferocious rule, and disreputable death. Many scholars largely agree with these remarks (his

\footnotetext{
${ }^{1}$ Conflict between the Romans and the Pathian Empire which was east of the Roman empire.
} 
cunning and violent nature) as factors that aided Herod to become king in addition to the fact that his kingship was prophesied twice (first by an Essence and second by a respected member of the Sanhedrin) before he was named king (Holzapfel 1996-1997:47, 60). The discussions here focus on the developments, achievements, and challenges of the rule of Herod.

\section{Religious Rule of Herod the Great}

Archbishop Kwasi Sarpong was emphatic that the Jews made no distinction between religion and politics. As a theocratic state, the high priest was also the political head. The High Priest decided on issues of social, economic, religious and political importance to the Jews; a position that is affirmed by Sarpong" (Sarpong 2016:5). To the Jews, politics and religion were the same thing, because they influenced and affected each other. For Herod to have become the political head of the Jews, signified a paradigm shift from the Jewish ideology of the priest also is the king. Unlike the Hasmonean period where the priest was the same as the king, Herod was only a political head. To consolidate his rule, Herod appointed his brother-in-law (Aristobulus III) as the high priest (Holzapfel 1996-1997:54). By such an action, Herod indirectly wielded religious power in addition to his political power. This distinction between religion and politics as practiced by the rule of Herod according to Holzapfel had three implications (Holzapfel 1996-1997:44). In the first place, it signified the end of the Hasmonean dynasty and its authority. Secondly, it was to consolidate his rule since it offered him the opportunity to appoint someone from the Hasmonean tribe to make the people feel they were part of the ruling class, although he killed him later. Thirdly, it signifies the respect Herod had for the Jewish faith where the Priest had to be from the tribe of Aaron but Herod was not from that line. Owing to his personal conviction as a Jew, he did not even have his image on his coins but rather used Jewish temple motifs (Holzapfel 1996-1997:59).

Herod, therefore, made important strides in the promotion of Judaism. His major contribution which could not be ignored by the passage of time was his building of the second Jewish temple, which began in $20 \mathrm{BC}$ and was completed in $\mathrm{AD} 63$, just seven years before its demolition (in 70 AD) (Beitzel 2014:311). According to Josephus, he started to build this temple in his eighteenth year and used a year and a half to complete it because, during the period of rebuilding, it did not rain especially during the day but only at night (Josephus 1998:308, 421). The magnificent Temple was described by Josephus (Josephus Ant. 15.330 425) as follows:

The exterior of the building was designed to astound the mind or eye. For, being covered on all sides with massive plates of gold, the sun was no sooner up than it radiated so fiery a flash that persons straining to look at it were compelled to avert their eyes, as from the solar rays. To approaching strangers it appeared from a distance like a snow-clad mountain; for all that was not overlaid with gold was of purest white...from its summit protruded sharp golden spikes to prevent birds from settling upon and polluting the roof...some of the stones in the building were 45 cubits in length, 5 in height, and 6 in breadth. The retaining wall was the most prodigious work that was ever heard of by man.

The Babylonian Talmud remarks: "Whoever has not seen the Temple of Herod has never seen a beautiful building" (Beitzel 2014:312). The rebuilding of the temple brought enthusiasm to the worship service of Judaism. The building of the temple helped to curb sectarianism in Judaism (Holzapfel 1996-1997:57). The absence of the temple meant that the Jews were 
meeting in the synagogues which possibly created some divisions that could foster breakaways, but the temple was an impressive tool to unify them. He did not only rebuild the temple but also paid for the full cost of training people to attend to the various responsibilities in the temple. That is to say, he equipped the priests with the capability to deal with the needs and requirements of the temple. Furthermore, Herod' 's temple was innovative. He introduced some new designs to beautify and make the temple more relevant. Unlike the first temple built by Solomon, the one by Herod had a place for the women and the gentiles. These parts made the temple more inclusive. The temple was so magnificent that according to Ferguson (2003:413) the Rabbis remarked that "He who has not seen Herod"'s temple has not seen beauty."

On the other hand, Murphy (2002:249) suggests that "For Herod, the temple served the dual purpose of advertising the magnificence of his rule and placating his Jewish subjects." The rebuilding of the temple was indeed extremely important for the reign of Herod. Furthermore, to entrench his political authority, he influenced the Jewish religious leadership. He increased the membership of the Sadducees to neutralize the impact of the Pharisees on the Sanhedrin. He further controlled the Sanhedrin with the introduction of his friends and associates to make sure his views were respected by the religious leaders (Holzapfel 1996-1997:54).

The contributions of Herod to the Jewish faith went as far as making the Romans respect the Jewish faith. Holzapfel (1996-1997:56) remarks that due to Herod's influence, the Romans developed a great respect for the Jewish faith and its institutions during various instances. Even those outside his control gained some respect in the diaspora wherever they were by gaining the freedom of worship, abstention from military service and sabbatical regulations. Furthermore, as a result of Herod's temple, the Jews who were scattered across the Roman empire sent taxes to Jerusalem according to the law (Holzapfel 1996-1997:57).

To a large extent, it can be argued that Herod contributed immensely towards making the promotion of the Jewish faith. He contributed to making the Jewish faith very strong, appealing and relevant. However, it would be naive to assume that Herod undertook these efforts for genuine religious reasons. Herod had some clandestine political motives for working towards the growth of the Jewish faith. Predominantly, Herod helped Judaism to consolidate its rule and to be loved by the people. The good thing was that he reaped some of the dividends he needed as the temple guaranteed some income for his administration. All this goes to buttress the point that Herod was a strategist and a great leader, who carefully calculated the impacts and results of his action before undertaking it. He did quite well for the Jewish faith although with ulterior motives.

\section{Economic and Infrastructural Developments}

Herod is often described as the Great because of his impact on the economy of his time as well as the peace and order which characterized his reign. Ferguson describes him as an able king because he successfully disbanded any foreseeable highway robbers or plunders and though a client king, he had his developmental plan intact (Ferguson 2003:413). There was peace and order in Jerusalem during his time because he was very firm and would not entertain the slightest suspicion but dealt with any possible break of the law decisively.

To this end, there was an economic boom during his time and agriculture flourished. Generally, Holzapfel (1996-1997:60) remarks concerning improvements in agriculture during the reign of Herod as: 
He improved trade routes, enlarged harbours, and created new markets for dates, wine, olive oil, asphalt and opobalsam. Other industries such as glass, pottery and perfume expanded significantly during his reign. Resettlement programs, agricultural development, and work relief gave the nation an unprecedented era of productivity.

Herod's improvement in trade and commerce made a lot of strides in businesses. Jerusalem was attractive to people even outside his jurisdiction. Many people from far and near came to Jerusalem for trading purposes with the Jewish people.

This economic boom helped to finance his developmental agenda. A noticeable aspect of Herod' 's rule which was his investment in infrastructure, was a result of the economic boom at his time. Murphy (2002:249) maintains that "In the Hellenistic world, the building was a medium of propaganda: an ambitious building program signifies wealth, power, and stability. ... buildings were a source of pride. To others, they symbolized the power of a well-entrenched ruler. To still others, they represented economic oppression." Herod invested massively in buildings to fit into the motives raised by Murphy (2002:249). Holzapfel suggests that Herod"'s building projects were unprecedented in the history of the Jewish people. He did not only build in Jerusalem, but his building spree spread even to other parts of the empire outside his jurisdiction (Ferguson 2003:413). He rebuilt the Solomon Temple with great innovations to the admiration of many, as already discussed. That was not the only temple he built. He built other temples even on gentile or pagan lands (Ferguson 2003:413). These temples were to serve his gentile subjects who may have become Jews. Many of Herod's projects were to score some political points, so his first building project was a fortress in honor of Mac Anthony in his capital named Antonia Fortress. It was both a palace and a fortress with very high walls and towers, moat, courtyard, baths as well as quarters for large troops (Holzapfel 1996-1997:50). To show his appreciation to Caesar he rebuilt the tower at Strato on the Mediterranean coast and renamed it Caesarea Murphy (2002:249). He further rebuilt Samaria and named it Sebaster which is Augustus in Greek, where he also built a temple in his honor Murphy (2002:249). Herod tried to secure his kingdom by building fortresses at Masada, Machaerus, Hyrcania, Cypros, Alexandrium, Atop, Jericho and Herodium (Holzapfel 1996-1997:50; Murphy 2002:249). He then built his most impressive palace-fortress called Central Palace. This palace was huge with three multi-storeyed towers and named after a friend (Hippicus), a son (Phasael) and his Jewish wife (Mariamme). All these projects were strategic to consolidate his rule and secure his kingdom. It must, however, be appreciated that despite Herod's political motive for these projects, they brought great comfort to the people under his rule.

Furthermore, Herod's rule contributed immensely to sporting activities. It could be inferred that Herod himself was a sportsman and thus enhanced the growth of sports and entertainment. $\mathrm{He}$ built both a theatre and an amphitheater in Jerusalem (Ferguson 2003:412). In 12 BC, he revived and supported the Olympic games which were almost defunct. He was made the president of the games in that year (Holzapfel 1996-1997:57).

All these building projects and activities of Herod contributed to making his government eventful in all respect. Holzapfel (1996-1997:62) shows why Herod invested heavily in buildings 
... reveal Herod's personality, fears, taste, and ambitions'. Some believe that the palace and fortress complexes reveal Herod's paranoia; the Jewish projects, a crafty plan to ingratiate himself with the religious element of his nation; and the non-Jewish construction projects, his deep commitment to Hellenism (even paganism). Whatever purpose these structures were intended to fulfil, they represent an ambitious enterprise, superbly implemented.

This comment goes to show that scholarship is divided about Herod's interventions for these ambitious projects. Broadly, the buildings could all be described as political. Herod was a great politician who would do everything to consolidate his rule. It could, therefore, be argued that Herod's philosophy was that when his people were happy, they were not likely to disturb his rule, therefore he went all out to provide them with what they needed so that there would be peace. These projects were important and relevant to the reign of the Herod named The Great.

\section{Excesses of the Reign of Herod the Great}

Despite his great impact on economics, politics, sports, and religion, Herod is noted for some atrocities against his subjects. Holzapfel describes the period as "fratricide, savagery, killing, conspiracy, civil disturbances, and international plots and counterplots" (Holzapfel 19961997:49). Herod, knowing the times too well, was brutal and lacked compassion for the people under him. He would kill a fly with a hammer. Murphy (2002:248) describes Herod as a cruel and merciless ruler of the Jews. One such low point in his rule was when Caesar visited Syria and the inhabitants of Gadara laid charges against Herod as "...heavy in his injunctions and tyrannical... injuries and plunderings, and subversions of temples...." (Josephus 1998:354, 357). Herod then made his defense before Caesar and was cleared off the charges. After this, Josephus recounts that "Herod released to his subjects the third part of their taxes, under the pretense of relieving them, after the drought they had experienced; but the main reason was to recover their goodwill..." (Josephus 1998:365). This shows how cunning Herod could be and the extent to which he could go just to keep his kingdom. Josephus continues further that Herod then

"took away the opportunity they might have to disturb him and directed them to be always at work; nor did he permit the citizens either to meet together or to walk or eat together, but watched everything they did, and when any were caught, they were severely punished; and many there were who were brought to the citadel Hyrcania, both openly and secretly, and were there put to death; and there were spies set everywhere, both in the city and in the roads, who watched those that met together (Josephus 1998:366).

This account shows that Herod would do anything to curtail any insurrection against him. He took away their rights to association and meetings. He was well informed that the ability of people to meet would offer an opportunity for consensus-building to affect his throne. People were not allowed to walk together even after work or to eat together. Those caught were openly or secretly sent to him to be punished while others were killed. The people's right to association and movements were restricted. He did not just end there, according to Josephus, Herod would sometimes disguise himself and mix with the people at night to know the citizen's views about his rule (Josephus 1998:367-369). After the disguise those he could not turn into friends, he would prosecute. He would make the rest swear an oath to obey and be faithful to him. This can be described as a kind of criminally liable oath not to say anything negative about king Herod. Josephus remarks that many of those who swore the oath did that out of fear. Even for 
Herod to get information from his victims, Herod would put such persons under severe physical torture (Holzapfel 1996-1997:55). This was normal practice at the time and Herod used it very often to gain whatever he wanted to know from the people.

Herod took firm decisions against anybody who stood in his way. He always wanted to be in control so anybody who stood his way needed to be put aside. As a result, many people, including the forty-five nobles of Antigonus II, were killed at Herod's instruction (Holzapfel 1996-1997:54). Many others disappeared in strange circumstances (Holzapfel 1996-1997:54). Of greater concern, was Herod's high-handedness in dealing with his own family. Herod did not mind if he had to kill members of his own family to secure his political power. He killed his wife Mariamme, whom he loved. He had married her to gain the support of the Jews. He killed her due to gossip from his sister against Mariamme. He also killed his wife's grandfather (Hyrcanus II), his mother-in-law (Alexandra), two of his brothers-in-law, his two sons with Mariamme (Alexander and Aristobulus) as well as another son Antipater and his uncle on suspicion that they wanted his thrown (Toher 2011:209). It was due to Herod's excessive executions even against his own family that Emperor Augustus was quoted to have remarked that one was better off being Herod's pig than his son (Ferguson 2003:4114). It is again due to these atrocious killings that the Christian account of Herod ordering children under the age of two to be killed when he heard that Jesus was born is believed (Matt. 2). Although many scholars have sought to find a corroborative account to this story, there seem to be nothing anywhere to back the gospel writer, yet as is said in Twi "Jno kwa" meaning someone who is noted for something, and so even when he has not done it, it is still believed he can do it and so invariably has done it.

It was due to Herod's cruelty that according to Josephus when it was rumored falsely that $\mathrm{He}$ had committed suicide, the people jubilated (Toher 2011:212). Herod after punishing the perpetrators of his purported death, many scholars believe that he devised a dubious plan. It is believed to have arrested some notable Jewish nobles and kept them in prison with the instructions that, at his death, they should also be executed. His aim was "that the country would be filled with lament rather than joy at his demise" (Toher 2011:2012). Although this was not carried out, it was well believed by many scholars probably based on the Akan 'ono kwa' maxim: Herod had done worse things in the past, so he could have done it. However, Toher (2011:212) argues strongly against this account because it was Herod's sister who spread this rumor.

Again, among the many challenges Herod had in his administration was the crisis in his family. There were major cracks within his household (Holzapfel 1996-1997:55). There was so much rivalry, suspicion, conspiracy and betrayal in his household. There were many occasions he was suspicious of his sons and wives especially Mariamme, which made him execute them. His sister and Mariamme, as well as her sons, did not see eye to eye. They antagonized each other many times and Herod's sister often won against them by poisoning Herod's mind against them, which eventually led to their ultimate death. There were many occasions where Caesar needed to settle Herod's family issues and sometimes Herod himself laid charges against his own family. It was as a result of these family challenges that Herod was believed to have changed his will six times before his death (Holzapfel 1996-1997:56). This showed the power struggles, betrayal, suspicion and bitter rivalry within Herod's own family. Such cracks and deep wedges created an unstable family. Herod did try his possible best to resolve these family crises. He was believed to have tried many times to unify his wives and children (Holzapfel 19961997:56). Despite his efforts, these excesses affected the rule of Herod and impacted him in the 
discharge of his authority. The acts of humiliation, atrocities, and murders undertaken by Herod affected the history of the Jews.

\section{LAST DAYS}

Herod's last days were full of betrayal, suspicions and family strife. On top of all this, Herod the Great was very sick. Josephus describes the terrible health condition of the last days of the man whose rule terrified many:

But Herod's sickness greatly increased upon him after a severe manner and this by God's judgment upon him for his sins: for a fire glowed in him slowly, which did not so much appear to the touch outwardly, as it augmented his pain inwardly; for it brought upon him a vehement appetite to eating, which he could not avoid to supply with one sort of food or other. His entrails also had ulcer and the chief violence of his pain lay on his colon; an aqueous and transparent liquor also had settled itself about his feet, and a like matter afflicted him at the bottom of his belly. Further, his genitals were rotting and produced worms; and when he sat upright, he had a difficulty of breathing, which was very loathsome, on account of the stench of his breath, and the quickness of its returns; he had also convulsions in all part of his body, which increased his strength to an insufferable degree ... God inflicted this punishment on the king on account of his great impiety (Josephus 1998:168-170).

To Josephus and many other Jewish people, this situation was placed on him by God as punishment for his obnoxious atrocities against his people. Josephus seemed to be happy for these predicaments that lay upon one man, who was called The Great. From the description, Herod had a fever, ulcer, intestine pains, abdominal ailment, and breathing difficulty among many other health conditions. Toher suggests that Josephus is likely to be pushing his bias too much by exaggerating the health condition of Herod (2011:213). This is because, the characterization of 'unendurable pain, infestation by worms, bad breath and skin eruptions' fit into a normal Roman ideology of 'death of a tyrant. Toher (2011:213) is not the only one who supports this position but he demonstrates other scholars such as Prause, Ladouceur, Africa, and Gauger who hold this position.

It is believed that this sickness began in 4 BC. When it all started, Herod knowing it was capable of killing him, changed his will to give his kingdom to his youngest son Malthace, Antipas who was just 21 years old (Toher 2011:211). However, during all this period of Herod's sickness, his eldest son with Doris, Antipater was nursing the ambition of becoming the next king and even participated in spreading the rumors of his father's death. Herod caught Antipater and kept him in prison. In the heat of his sickness, Herod was then reported to have attempted suicide with a knife but was stopped by his cousin Achiabus (Josephus 1998:184). Antipater then tried to take advantage to bribe the jailer to take the thrown. Herod heard of this and five days before his death, he ordered the execution of Antipater. Furthermore, in the last three or four days, he changed his will again and divided his kingdom to his three sons (Antipas, Philip, and Achelaeus). However, in recent work by Gunther as cited by Toher, Herod rewrote his will after 
the conviction of Antipater and neither did Herod attempt suicide but all these were recorded to show the level of disorder in the house of Herod after his death (Toher 2011:218). Also, because the execution of Antipater and the death of Herod were made possible almost a week after they happened. Josephus then says "When he had done these things, he died, the fifth day after he had caused Antipater to be killed; having reigned, since he had procured Antigonus to be killed, thirty-four year; but since he had been declared king by the Romans thirty-seven..." (Josephus 1998:191). It means, therefore, that Herod started his reign with killing and ended it with killing. He was eventually given a befitting burial led by his son Archelaus who mourned him for seven days (Josephus 1998:196-200).

This is the account of the rise and fall of the Great man known as the king of the Jews. Though he did very well for the kingdom of the Jews he also committed certain atrocious crimes that were unprecedented in the history of the Jews. Many of the things he did were innovative, visionary and focused.

\section{GHANA'S FOURTH REPUBLIC}

Ghana, like many other African countries, was once colonized. In 1957, Ghana's Jsagyefo Dr. Kwame Nkrumah led the country to become the first sub-Saharan African country to gain independence. Dr. Nkrumah assured the world that Ghana was prepared to lay her own economic and political foundation and build upon it. Unfortunately, post-independence Ghana has witnessed social and political violence and bloodshed through coup d'état and military rule. In 1992, Ghana decided through a referendum to go back to constitutional rule. For more than two decades now, Ghana has enjoyed political stability with seven peaceful general elections of a four-year term each successfully conducted. Ghana is presently politically stable.

The period under study is the Ghanaian Fourth Republic, which spans from 1992 to date. Prior to this period, Ghana had faced a lot of political instability characterized by several military coup d'états. The Fourth Republic has witnessed eight elections with the two main political parties, the National Democratic Congress (NDC) and the New Patriotic Party (NPP) dominating. The NDC has won four out of the six elections. They won in 1992, 1996, 2008 and 2012. The NPP won in 2000, 2004, 2016 and 2020. This paper, therefore, seeks to compare the political life of Herod to the politics of the Fourth Republic of Ghana. The main aim of this comparison is to find out if the politics at the time of Herod and the politics of today have any similarities.

\section{Political campaigns in Ghana compared to Herod's time}

The political regimes of the two periods are very different. The Roman period was an imperial system which can be described in the present term as "colonialism." The Jewish territory could be described as a colony of the Roman Empire. The political head was appointed by the emperor and he acted as a "client king" of the emperor. Ferguson (2003:45) affirms that Herod and his descendants were client kings who ruled Palestine on behalf of the Romans. The client kings had political, economic and military powers over the areas of their administration. However, the modern system of democracy is preferred among nations including Ghana, although Ghana before 1957 was a colony of the British. The democratic system means the people ruled themselves by choosing who should be the head. However, during this period, a lot of things have been done by the various candidates to secure votes. In the days of Herod, 
people were murdered in civil wars which is not different from what the politicians of today do. During the Ghanaian Fourth Republic, there have been many murders and killings believed to have been influenced by some political motivations. Though none of the killings was confirmed as politically motivated by the police or any official agency of the state, most Ghanaians believed the killings were carried out by politicians or agents of people seeking political power. Before the 2000 election, there was great insecurity among Ghanaian women. Almost every morning, Ghanaians woke up to find a woman murdered somewhere in the country. Most Ghanaians concluded the killings to be for political reasons because of the way and manner they occurred. First, it was only women that were killed during that time. Secondly, it is alleged that all the murdered women had a part of their body cut off, in most cases their private parts or breasts, making the rumors of the killings being for ritual purposes gain currency. Finally, all these murders took place in an election year; and the fact that it stopped just after the 2000 elections gave it political color and flavor. Recently a regional Chairperson of the NPP was bathed in acid which led to his death, because of political rivalry believed to be between people in the same political party. ${ }^{2}$ The year 2020 was also characterized by electoral violence, predominantly involving the NDC and the NPP. The decision by the Electoral Commission to compile a voters' register was contested by the NDC who thought it was a waste of state resources and an event that would increase people's risk of contracting the COVID-19 virus. Finally, when the exercise took place, there was a series of violence including gunshots at some registration centres, which claimed lives and injured many people.

The NDC also has cases of politicians who have been stabbed but not fatal, all to win political power such as in a case where a treasure stabbed twice a chairman in the Ahafo Ano North constituency of the NDC. ${ }^{3}$ There are countless instances of disorder that take place in this modern era similar to what went on before Herod securing political power. Although the forms of disorder in Herod's period have changed from what we see today, the motivation is the same: to get power at all costs. If anybody or anything stands in the way of the politician, that person or thing must be eliminated.

Religion is another important strategy politicians use to secure political power. Herod needed to get the people to like him so he built the temple and married into the Hasmonean family to get the support of the Jews. In these modern times, the politician is very much aware of this phenomenon in the words of Mbiti (1969:1), "Africans are notoriously religious...." Because of this, politicians use religion to help them obtain the goodwill of the people to capture political power. Kwesi Yankah remarked in The Mirror newspaper as cited by Elom Dovlo (2006:5) that "suddenly it has been realized that the shortest route to the castle (the seat of government was in the Christiansburg Castle) is the church." To this end, Dovlo recounts the show of the main presidential candidate's affinity to the Christian faith when Kwabena Darko, the flag bearer of the National Independence Party (NIP) in the 1992 Presidential election tells of his visionary call by God to be a president. Kwabena Darko was one of those who introduced the Full Gospel Businessmen Fellowship International in Ghana (FGBFI) and his wife also among those that initiated the Women's Aglow. Dovlo maintains "it was the Christian qualities of Darko and his wife that formed the pivot of his campaign" (Dovlo 2006:6). Similarly, Prof. George Hagan, the flagbearer of the Convention Peoples Party (CPP) was given a huge space in the Catholic Standard of Friday, $11^{\text {th }}$ September 1992 to highlight his Christian background.

\footnotetext{
2 http://www.myjoyonline.com/politics/2015/May-21st/upper-east-assailants-pour-acid-on-npp-chairman.php $12 / 11 / 16$

${ }^{3}$ http://viasat1.com.gh/news/local/article.php?postId=8507 12/ 11/16
} 
He and his mother had received papal awards as well as his father being a strong member of the Knight of Marshall. On the side of the NPP, their presidential candidate who was known over the years as Adu Boahen, a distinguished historian of the University of Ghana, was all of a sudden called Albert Adu Boahen, just to underscore his Christian convictions and to win votes from the Christian electorate. Furthermore, the Christian Messenger granted him an interview to draw attention that he was a Christian. The Statesman newspaper which was affiliated with the NPP did a publication on $8^{\text {th }}$ November, 1992 giving ten reasons why people must vote for him and the tenth was that 'he (Adu Boahen) feared God (Dovlo 2006:8).

In all of this, another aspect of the use of religion by the Ghanaian politicians to win the hearts of the people just as Herod did to be loved by the people is the use of sacred spaces and religious songs. This is apparent during every Ghanaian political season. The politicians go to almost every religious gathering for the campaign. Dovlo recounts a lot of these examples. Recently, it was reported that Vice President Kwesi Amissah Arthur visited a retreat organized by the Church of Pentecost for her Pastors to distribute copies of the 'Green Book' - a book chronicling the (infrastructural) achievements of the NDC administration. ${ }^{4}$ On the other hand, the presidential candidate of the NPP visited five churches one Sunday in Takoradi. ${ }^{5}$

The use of Christian or gospel songs is another strategy by most politicians to win votes. The NDC uses the Christian tune 'Onward Christian Soldiers and the Christian song "Wo ke Yesu baya" ("We will go with Jesus") among others while the NPP has used Christian songs such as "Satan crying in defeat", Awurade Kasa ("Speak Lord!"), "Go High" and many others. All these songs and Christian slogans such as the 'battle is the Lord's and symbols such as President Mahama looking into the heavens with one hand lifted to God, signifying that his help comes from the Lord. These gimmicks are all employed to win the heart of the populace. In the 2016 elections, religion played a very important role especially in the order of placing of the candidates on the ballot papers which was done by picking the ballot papers to form a container randomly. The Convention People's Party (CPP) picked the first place which they interpreted as God has ordained the CPP to be first. The NDC picked the third-placed and they interpreted it as "John 3:16" thus their candidate is John (Mahama) who is third on the ballot in the 2016 election. The text of the verse also indicates that John Mahama is God-sent to save Ghana. The Progressive People's Party (PPP) picked the fourth place and they claim it means "God is with us", explaining that this phrase is made up of four words. The NPP also picked five and they claimed, it means Grace, Bible, Quran; implying that all these words are made up of five alphabets. Significantly David used five stones to combat Goliath, so five is significant. ${ }^{6}$ Additionally, an Islamic numerologist added his voice by explaining what number five on the ballot meant for the NPP candidate whose name is Nana Addo Danquah Akuffo Addo (made up of five names), he is an indigene of the Eastern Region with an Elephant as his party symbol (where $\mathrm{E}$ is the fifth alphabet), his home town is Kyebi (a five-letter word) among other interpretations. ${ }^{7}$ Incidentally, during their manifesto launch few months before the balloting; the flag bearer Nana Addo Danquah Akuffo Addo quoted 1 Samuel 17:41-47, ${ }^{8}$ claiming that "... the battle is the Lord's" (1 Sam. 17:47). In the 2020 elections, the NDC picked the number 2 on the ballot paper. Immediately after the ballot, a parousia theology emerged whereby

${ }^{4}$ http://m.peacefmonline.com/pages/local/social/201605/278840.php 14/11/16

${ }^{5}$ http://www.ghanamma.com/2016/02/15/nana-storms-5-churches-in-takoradi/ 12/11/16

${ }^{6}$ http://www.peacefmonline.com/pages/politics/politics/201611/297765.php 12/11/16

${ }^{7} \mathrm{http} / / / \mathrm{www}$. peacefmonline.com/pages/politics/politics/201611/298540.php 18/11.16

${ }^{8}$ http://www.ghananewsagency.org/politics/the-battle-remains-the-lord-s-nana-akufo-addo-108832 15/11/16 
people explained that by picking a second place on the ballot paper, the NDC candidate John Dramani Mahama was going to win the election and be President for the second time. In other words, the second position on the ballot paper signified the "second coming" of John Dramani Mahama who had been president for one term before, from 2012 to 2016. The parousia theology made followers of the NDC confident that their candidate was going to win the elections. The role of religion in politics cannot be overemphasized especially during the campaigning period. Herod equally used this as a strategy to win the hearts of the people, built a temple and married a daughter of the Hasmoneans to be loved by the Jews. The politics at the time of Jesus and today indeed used religion to achieve their aims.

\section{COMPARISON OF HEROD TO THE GHANAIAN FOURTH REPUBLIC}

There are many similar examples of political happenings during the reign of Herod and that of politics in the Fourth Republic of Ghana. The discussion here is to compare the economic development of Herod, his brutalities, disappearances, and the hoax of his purported death which marked the reign of Herod and the Ghanaian fourth republican era.

It is important to stress here that Ghana, just like Palestine before the colonial rule was governed by the chiefs. The Jews were regulated by Torah under their religious leaders, who had both religious and political powers. However, when the Roman hegemony set in with the complex system of government, the power was divided where Herod controlled the political rights and the religious bodies had religious responsibilities. Ghana equally had a similar system, where chiefs are both political and religious leaders of their societies. Although it is believed that the political authority of the chiefs has not been taken over by the government, he cannot declare war as they did in times past. Like the Jews, the separation between politics and religion was ushered into Ghanaian life by the colonial masters. To this extent, even later when the priests speak on political issues in Ghana, the politicians are quick to advise them to confine themselves to keep religious duties and leave governance to the elected bodies. ${ }^{9}$

Launching the comparison between Herod and the politics of Ghana, Herod engaged in extensive building projects to show the might of his rule. It is rather interesting that the situation is similar in Ghana. During the 2000 election, the NPP accused the ruling NDC of not doing anything for the nation. The NDC responded that they had built roads and extended electricity to the rural areas. The NPP quickly retorted, 'are we going to put a road in a plate with fork and knife in hand to eat? ${ }^{10}$ Going into the 2008 elections, the NDC also accused the NPP of not doing anything to help the nation and the NPP also responded to having built roads and other infrastructures. The NDC equally asked if the citizens would eat roads and those infrastructures. In view of this, then President John Agyekum Kuffour published a book to show the developments his government had achieved. To the extent that, even uncompleted projects were commissioned because John A. Kuffour was leaving office and he needed to emboss his name on the plaques as a sign that he built the projects. The president is believed to have even commissioned toilet facilities. ${ }^{11}$ Interestingly, the same trend is still going on with the ruling NDC administration, the then President, John Dramani Mahama has had to publish a book entitled 'Green book'. Almost everything in that book is to demonstrate the infrastructural development of the ruling government. The building of schools, markets,

\footnotetext{
${ }^{9}$ http://www.peacefmonline.com/pages/politics/politics/201605/278437.php 11/11/16

10 http://www.myjoyonline.com/politics/2016/july-14th/we-dont-eat-roads-but-roads-determine-what-you-eatmahama.php 13/ 12/16

${ }^{11}$ http://politics.myjoyonline.com/pages/news/201106/67166.php 21/11/16
} 
hospitals, and stadia are some examples of such infrastructures. It is therefore very interesting to observe that over the centuries, politicians maintain they should be judged by the level of infrastructure they add and contribute to the developments of the nation. Herod focused on buildings and in our current dispensation; the Ghanaian politicians are no different from Herod. They still build various structures including roads.

Another activity in the days of Herod which still marks politics today in Ghana has to do with killings and disappearances. Although the killings in the days of Herod were rather personal and sometimes based on suspicions, the killings today are rather different. Today, due to democratic principles and international charters on human rights such killings cannot be done on such a large scale as Herod may have done. However, in the first part of the fourth republic, the Ghanaian political landscape witnessed killings and murders that were largely suspected to be politically motivated. ${ }^{12}$ Furthermore, in these killings, it is believed among the Ghanaian people that whenever elections are around the corner, some of the politicians try to seek supernatural powers for their campaigns and so they need human blood to secure the power they so much desire. These ritual murders were very rampant, especially in the 2000 elections. Even more, it is suspected that the killing of a sitting Member of Parliament for Abuakwa North constituency (Joseph Boakye Danquah Adu) has some political inclinations. ${ }^{13}$ It is believed that his murder was a political assassination among a section of the political divide. These and many other killings are although not the same as the case of Herod, all fit into the political ideology because the aim is to secure and protect political power. Herod killed those he was suspicious of while in today's politics, the Ghanaian politician may kill even innocent people to get some magical power to secure votes and political power. All of these go-to stress the point that bloodshed in the name of political power has been there since time immemorial and we cannot predict if it will ever go away anytime soon.

Furthermore, it can be recalled that Herod, at a point ruled that people should not meet, not even walk or eat together. At night he would disguise himself and walked among the people to gather information and those who spoke ill of his rule were charged or killed. These practices of Herod are similar to what became known in Ghana as the 'culture of silence. A person could not criticize the government or say anything ill about the government or its functionaries. Ghana had what was known as criminal libel law, which gave government appointees the power to prosecute anybody who said or wrote anything they deemed as libel to be fined or jailed. ${ }^{14}$ When the NPP came into power in 2000, it was one of their greatest achievements which they kept trumpeting when they repealed criminal liable law. ${ }^{15}$ Today, many Ghanaians feel the same when due to the 2016 elections the Inspector General of Police suggested that there is a need to block social media on Election Day. Many Ghanaians said he wants to bring back the culture of silence. ${ }^{16}$ The blocking of social media will prevent people from sharing what is on their minds and will impede the quick flow of information which the populaces are not ready to sacrifice. We certainly are not far at all from the days of Herod where people's

12 http://www.ghanaweb.com/GhanaHomePage/NewsArchive/Politicians-will-sacrifice-children-for-2016election-votes-406479 05/12/16

${ }^{13} \mathrm{http}$ ://citifmonline.com/2016/02/13/i-had-no-hand-in-jb-danquahs-killing-stan-dogbe/ 05/12/16

${ }^{14}$ https://www.modernghana.com/news/15786/1/criminal-libel-law-repealed.html 05/12/16

${ }^{15}$ https://www.modernghana.com/news/15786/1/criminal-libel-law-repealed.html 23/11/16

${ }^{16} \mathrm{http} / / /$ www.myjoyonline.com/news/2016/May-26th/igp-considers-blocking-social-media-on-election-day.php $14 / 11 / 16$ 
rights of association, speech, and movements were curtailed. The Ghanaian fourth republic has seen cases of human rights being curtailed for political reasons.

A final aspect of the Ghanaian fourth republican era which is similar to that of Herod is in the area of the hoax of the death of some politicians. Herod was said to have died and the whole of Jerusalem went into jubilation. This kind of thing is not new to Ghanaian politics. Many politicians have been proclaimed dead on several occasions. The former party chairman of the NPP, Jake Obestebi Lamptey was before his death rumored to be dead. His people came quickly to debunk the rumor but he died three months after. ${ }^{17}$ Another person is the former president John Kuffour who was rumored to be dead but it was not true. ${ }^{18}$ If there is any other person who was a victim of this death hoax, it must be the late former president John Evans Atta Mills. The former president on countless occasions was rumored to be dead. He was rumored to be dead when he first lost the presidential bid to President Kuffour, later even when he was the president, this death hoax persisted. Therefore when he died, many people did not believe it for the first few hours. Death hoax, for whatever political gains, has been very much a part of politics from time immemorial and may continue for some time to come. The sad aspect is that it is difficult to trace the source of these rumors but it drives home the point that this is something that has existed for a long time.

All these examples of happenings during the reign of Herod compared to the Ghanaian fourth republic indicate that times have not changed that much. The politics of today is not too different from the politics of the time of Jesus.

The final part of this comparison is to take a look at the last days of Herod and see if there are any semblances with the Ghanaian situation today. It is a difficult thing to do because in our part of the world, death is not really discussed and it is also unethical to discuss other people's health especially the health of politicians. Despite all these, in the Ghanaian Fourth Republic, however, only one out of the four ex-presidents have died. President John Evans Atta Mills died three days after his sixty-eighth birthday on $24^{\text {th }} \mathrm{July}, 2012$ as a sitting president. His death was a great blow to the nation since the nation was only five months away from elections and he was billed to contest the election. The president was known to be sick for the major part of his administration so he left a lot of things in the hands of his thenVice President John Dramani Mahama. There was even an occasion he appeared in public and his palms were black. ${ }^{19}$ an indication that he was not in the best of health. Many expressed worry about it and the then Deputy Minister of Information Hon. Okujeto Ablakwa responded that he was only reacting to some drugs his doctors had given him. ${ }^{20}$ There was another occasion where when he went for a medical checkup in the USA, and there were rumors that he was not coming back alive. On his arrival back in Ghana, though in suit and tie and dark glasses, the president began to jog at the airport to show everybody that he was well and healthy to continue as the President of the nation. ${ }^{21}$ Not too long after this show of fitness, in the afternoon of Thursday, $24^{\text {th }}$ July, 2012 the President was reported dead. The sad result of trying not to let the people know of the true state of health of the President was that it led to suspicions as to what caused his death. Many

\footnotetext{
${ }^{17}$ http://www.peacefmonline.com/pages/politics/politics/201512/264103.php 14/11/16

${ }^{18}$ http://www.ghanaweb.com/GhanaHomePage/NewsArchive/Death-Hoax-Ex-Prez-Kufuor-s-family-not-happy344591 14/11/16

${ }^{19}$ http://www.modernghana.com/ghanahome/newsarchive/news_details.asp?id=307723\&menu id=1\&title=why -prez-mills-hands-are-black.html 23/11/16

${ }^{20}$ http://niihalifax.blogspot.com/2010/12/why-prez-mills-hands-are-black.html 05/12/16

${ }^{21}$ http://www.peacefmonline.com/pages/politics/politics/201206/120873.php 23/11/16
} 
Ghanaians believe that the nation was not told the truth about the cause of the death of the President thus leading to various conspiracy theories as to why the sitting President died. ${ }^{22}$

\section{CONCLUSION}

It is noteworthy, that the words of the wise king Solomon are still relevant today. There is indeed nothing new under the sun. Society seems to be moving in concentric circles or repetitions. The events of $30 \mathrm{BC}$ to around the year $4 \mathrm{AD}$ seem to be no different from that of the $20^{\text {th }}$ and $21^{\text {st }}$ centuries. Things have not changed much; the politicians of today just like those in Herod's day will do anything to obtain political power. It does not matter if lives must be lost, they can be brutal just to secure what they want, rather than to lose it to any other person. They often scheme, even if they have to compromise certain aspects of their own lives including religion, to obtain the mandate of the people. Politics at the time of Jesus has not changed much from that of today, they are almost the same and to borrow the jargon in Ghana when the cedi was revalued, Ghanaians were told that 'the value is the same.' Indeed, the politics at the time of Jesus is no different from what is happening in Ghana using the fourth republican period as a model to the rule of Herod the Great. Therefore, it is true that 'there is nothing new under the sun'.

\section{REFERENCES}

Beitzel, Barry J. 2014. "Herod The Great: Another Snapshot Of His Treachery?” JETS 57/2, 309-322.

Dewberry, William 2013. The Divine Seed. Bloomington: Authorhouse.

Dovlo, Elom. 2006. "Religion and the Politics of the Fourth Republican Elections in Ghana (1992, 1996)" in Ghana Bulletin of Theology. Vol. 1 No. 1, Accra: Department for the Study of Religions.

Ferguson, Everett. 2003. Background of Early Christianity. 3rd Edition. Michigan: William B. Eerdmans Publishing Company.

Holzapfel, Richard N. 1996-1997. "King Herod." Masada and the World of the New

Testament. Brigham Young University. 36, no. 3: 35-73.

Josephus, Flavius. The Complete Works translated by William Whiston. Grand Rapids: Kregel Publications, 1999.

Mbiti, John S. 1969. African Religious Philosophy. Oxford: Heinemann Educational Publishers.

Murphy, Frederick J. 2002. Early Judaism: The Exile to the Time of Jesus. Massachusettes: Hendrickson Publishers.

Powell, Mark Allan. 2009. Introducing the New Testament: A Historical, Literary, and Theological Survey. Grand Rapids: Baker Academic.

Sarpong, Peter K. 2016. The Church and Politics: the Ghanaian Experience, Public Lecture delivered at the Catholic Institute of Business and Technology.

Toher, Mark. 2011. "Herod's Last Days." Harvard Studies in Classical Philosophy 106: 209228.

22 https://www.modernghana.com/news/411220/1/who-and-what-killed-president-john-evans-atta-mill.html $26 / 11 / 16$ 